\title{
Distinguishing pedogenic and non-pedogenic silcretes in the landscape and geological record
}

\author{
J. Stewart Ullyott ${ }^{a, \star}$ and David J. Nash ${ }^{a, b}$
}

a School of Environment and Technology, University of Brighton, Brighton BN2 4GJ, United Kingdom

b School of Geography, Archaeology and Environmental Studies, University of the Witwatersrand, Private Bag 3, Wits 2050, South Africa

* Corresponding author. Tel.: +44 1273 642267; Fax: +44 1273 642285. Email address: j.s.ullyott@brighton.ac.uk (J.S. Ullyott)

\begin{abstract}
Silcrete is a type of duricrust formed by the near-surface accumulation of secondary silica within a soil, sediment, rock or weathered material. A variety of models of formation have been put forward, involving silicification in both pedogenic and non-pedogenic settings. The resulting silcrete types differ in terms of their macroscale characteristics, micromorphology, areal extent and behavioural properties. Such differences have significant implications in a range of geological, geomorphological, archaeological and engineering contexts, making the correct identification of silcrete type of considerable importance. This paper reviews the properties of pedogenic, groundwater, drainage-line and pan/lacustrine silcretes, and identifies many characteristics that may be diagnostic. It also discusses a number of more problematic macro- and micro-scale features common to both pedogenic and non-pedogenic silcretes. It concludes with a short checklist to aid the future identification of different silcrete types in the landscape and geological record.
\end{abstract}

Keywords: Duricrust; groundwater silcrete; pedogenic silcrete; micromorphology; silicification; puddingstone; sarsen 


\section{Introduction}

Silcrete is a variety of highly indurated duricrust formed as a result of the near-surface accumulation of secondary silica within a soil, sediment, rock or weathered material (cf. Summerfield, 1983c; Milnes and Thiry, 1992). It is particularly widespread in Australia (e.g. Thiry and Milnes, 1991) and southern Africa (e.g. Summerfield, 1982, 1983a), where it is commonly found outcropping in association with ancient land surfaces. Silcrete also occurs as more spatially limited outcrops, as a surface lag or as isolated boulders in many other areas, including western Europe (see Nash and Ullyott, 2007 and references therein). The sarsens and puddingstones of the southern UK are a good example of the latter. Silcrete is also widely documented in geological contexts from borehole data (e.g. Rogers, 1980; Basile-Doelsch et al., 2005).

Four main types of silcrete are recognised in the literature (Milnes and Thiry, 1992; Nash and Ullyott, 2007) (Fig. 1.). The most widespread, in terms of areal extent, are pedogenic silcretes (Fig. 2.). These develop within soil profiles as the result of a succession of phases of silica dissolution and recrystallisation caused by multiple episodes of water infiltration and percolation (e.g. Thiry, 1978, 1988; Thiry et al., 2006). Other silcrete types are often grouped together, for convenience, as non-pedogenic varieties (Fig. 3.). Of these, groundwater silcretes form under phreatic conditions through silicification at or close to a water table, or at zones of groundwater outflow (e.g. Callen, 1983; Thiry et al., 1988; Thiry and Milnes, 1991; Thiry et al., 2015). Drainage-line silcretes, in contrast, develop as a result of the silicification of alluvial fills in contemporary or former fluvial systems (e.g. Young, 1978; van der Graaff, 1983; Leckie and Cheel, 1990; Nash et al., 1998; Shaw and Nash, 1998). A final variant, termed pan/lacustrine silcrete by Nash and Ullyott (2007), forms as a result of the silicification of sediments at the margins of ephemeral lake basins (e.g. Goudie, 1973; Summerfield, 1982; Bustillo and Bustillo, 1993; Armenteros et al., 1995; Nash and Shaw, 1998; Bustillo and Bustillo, 2000).

Silcretes develop in a variety of landscape settings and over different timescales (Thiry, 1999). Investigations in Australia and South Africa, for example, show that pedogenic silcrete formation is directly associated with the development of palaeosurfaces (e.g. Mountain, 1952; Langford-Smith, 1978; Wopfner, 1978; Mountain, 1980; Summerfield, 1983a; Alley, 1998); thus the silcrete effectively forms on or very close to a former land surface. Silicification in this context proceeds over potentially large areas and at timescales of $>10^{6}$ years via the gradual progradation of the silcrete profile into the landscape (Thiry and Milnes, 1991; Milnes and Thiry, 1992). In contrast, non-pedogenic 
silcrete development may be more localised, and is often controlled by the position of the local water table; while this would imply an overlying palaeosurface, the silcrete itself does not mark the position of the former land surface (e.g. Callen, 1983; Nash and Ullyott, 2007). Formation may also be much more rapid. Studies at Fontainebleau (Paris Basin), for example, reveal superposed groundwater silcrete lenses developed during phases of landscape incision, with individual lenses forming in the order of 30,000 years (Thiry et al., 1988; Thiry, 1999).

The above processes of silcrete formation lead to end-products that differ in terms of their macro- and micro-scale characteristics (see Figs 2. and 3.), areal extent and behavioural properties. Such differences have significant implications in a range of geological, geomorphological, archaeological and engineering contexts, making the correct identification of silcrete type of considerable importance.

As an illustration, the misidentification of a pedogenic silcrete as non-pedogenic could be problematic to the formulation of models of landscape evolution, primarily due to the differences in the geomorphological context of, and time required for, profile development noted above. It would also impact upon palaeoenvironmental interpretations. Pedogenic silcrete formation is thought to be restricted to areas of past or present tropical to subtropical climate with alternating wet and dry seasons or periods, whereas nonpedogenic silcretes may have formed in a variety of environmental settings and under climates ranging from cold to arid (e.g. Milnes and Thiry, 1992; Ullyott et al., 1998; Webb and Golding, 1998; Thiry et al., 2015). Many interpretations of UK silcretes (e.g. Summerfield and Goudie, 1980; Jones, 1999; Lovell, 2015) have inferred, by analogy with southern African and Australian pedogenic silcretes, that they formed as part of an extensive stable palaeosurface under tropical or sub-tropical conditions. However, other studies (Ullyott et al., 1998, 2004, 2015; Ullyott and Nash, 2006) indicate that the majority of sarsens and puddingstones are non-pedogenic in origin, and hence could have formed in different palaeoclimatic contexts. Further, detailed studies of sarsen boulders and debris in plough soil, older buildings and in archaeological contexts suggest that, at least for some areas (e.g. Salisbury Plain and the eastern South Downs; Green, 1997; Ullyott et al., 2004), silcrete distribution was patchy rather than continuous.

From an applied perspective, misidentification of silcrete type could generate problems for basin analysis and sequence stratigraphy. Pedogenic silcretes form within soil profiles that may transect a number of formations on stable basement or basin-marginal areas (Thiry, 1978; Callen, 1983; Milnes and Thiry, 1992) and indicate a hiatus or unconformity, 
whereas non-pedogenic silcrete is normally either intraformational or develops within the host material long after deposition. The characterisation of aquifers and hydrocarbon reservoirs, and the development of engineering ground models (e.g. Fookes et al., 2013), also requires the accurate identification of silcrete type. Although the lateral continuity of silcrete bodies is often hard to determine, particularly where an original outcrop has been broken up by erosion, pedogenic silcretes are usually more extensive than other types (Thiry and Milnes, 1991). They may also be thicker and, because of their profile characteristics (Section 2), more permeable than non-pedogenic varieties. Finally, there is growing evidence from the archaeological literature that pedogenic silcrete has different knapping properties to non-pedogenic, the former requiring heat treatment prior to use in stone tool manufacture (Brown et al., 2009; Schmidt et al., 2013) while the latter is workable untreated (Nash et al., 2013). Consequently it is essential that studies trying to provenance artefacts are able to recognise differing silcrete types at their source outcrops.

While the literature on silcrete is relatively large, and there have been a number of useful reviews that include descriptions of silcrete properties (e.g. Milnes and Thiry, 1992; Thiry, 1999; Nash and Ullyott, 2007), few of these have adequately synthesised the macro- and micro-scale differences between silcrete types worldwide. The aim of this study is to establish criteria for distinguishing between pedogenic and non-pedogenic silcretes, both in the field and in the geological record. We also identify areas of remaining uncertainty that would benefit from additional research.

\section{Characteristics of pedogenic silcretes}

Pedogenic silcretes exhibit a number of diagnostic characteristics. Foremost amongst these is the presence of a complex profile organisation, with macro- and micromorphology varying consistently throughout. 'Typical' pedogenic profiles can be differentiated into two sections at the macroscale. The upper part is usually highly indurated and features well developed vertical jointing, giving a columnar appearance (Goudie, 1973; Thiry, 1978; Wopfner, 1978; Callen, 1983; van der Graaff, 1983; Thiry, 1988; Dubroeucq and Thiry, 1994; Ballesteros et al., 1997; Thiry, 1999; Thiry et al., 2006) (Fig. 2a-c); this may be overlain by a pseudo-brecciated or, less commonly, a pseudo-nodular horizon. Macroscopic geopetal ('way up') features, including laminated drapes, and/or cap-like or drip-like forms (Fig. 2b) are widely documented (Thiry, 1978; Summerfield, 1981; Callen, 1983; van der Graaff, 1983; Webb and Golding, 1998; Baele et al., 2012). The lower section of the profile often exhibits a nodular or granular appearance and is typically less 
consistently cemented (Thiry, 1978; Watts, 1978; Thiry, 1981; Milnes and Twidale, 1983; Summerfield, 1983b).

When viewed in thin-section, pedogenic silcretes exhibit a number of microfabrics (Fig. 4) indicative of the role of soil-forming processes in their formation (e.g. abundant cutans, caps and eluvial structures, nodules/glaebules [Fig. 4a-b]; Thiry, 1999), with primary features of the parent material normally obliterated during the silicification process. Geopetal structures comprising alternating lamellae of silica and titania (e.g. Frankel and Kent, 1938; Taylor, 1978; Thiry, 1978, 1988; Terry and Evans, 1994; Curlík and Forgác, 1996), or silica with iron or manganese oxides and clays (Ballesteros et al., 1997; Thiry et al., 2006), are frequently well developed and abundant. These illuvial or 'colloform' features (Fig. 4b-f) occur in a variety of forms, often as vertically-stacked concave-upward cusps apparently infilling voids or dissolution features (Summerfield, 1983c), as conical or cap structures on top of host sediment clasts or silcrete fragments, or as drip-like features beneath clasts (Thiry, 1978, 1981; Callen, 1983; van der Graaff, 1983; Thiry, 1988; Thiry and Milnes, 1991). In UK silcretes, illuvial features comprising alternating lamellae of silica and titania have only been reported from sarsens and puddingstones on the East Devon Plateau (Isaac, 1983).

The micromorphology of pedogenic silcrete indicates an interplay between dissolution and percolation throughout the profile (Milnes and Thiry, 1992). Dissolution and eluviation features dominate the upper part of profiles, while illuvial structures typify the lower horizons (Thiry, 1978; Watts, 1978; Thiry, 1981; Milnes and Twidale, 1983; Summerfield, 1983b; Thiry and Ben Brahim, 1990; Kendrick and Graham, 2004). The origin of this differentiation is unclear, but appears to be related to gravitational movement of solutions under alternating wet and dry conditions.

While the macro- and micro-scale features described above are common to all pedogenic silcretes, there may be variations in mineralogy, geochemistry and cements between profiles. Two predominant types of pedogenic silcrete have been identified. The first exhibit profiles where microquartz is the dominant cement, with enrichment in titania usually identified as 'leucoxene' or anatase (e.g. Thiry, 1978, 1988). Upwards increases in the crystallinity of silica cements, often termed vertical ripening, is commonly observed at the profile scale in this type, with quartz cements present in addition to microquartz in upper sections and opaline silica more typical at the base (Thiry and Millot, 1987). The second type of pedogenic silcrete exhibits predominantly opaline cements, contains goethite and hematite, sometimes alunite, and retains clay minerals (e.g. Meyer and Pena 
dos Reis, 1985; Thiry and Turland, 1985; Ballesteros et al., 1997; Thiry, 1999). Evidence of vertical ripening may also be apparent (Ballesteros et al., 1997), with microquartz and chalcedony cements present in upper parts of the profile.

\section{Characteristics of non-pedogenic silcretes}

In contrast to pedogenic silcretes, the majority of non-pedogenic silcrete varieties display both a much simpler profile structure and micromorphology (Fig. 3). Groundwater, drainage-line and pan/lacustrine silcretes typically occur as discontinuous lenses (Fig. 3a), or as tabular sheets, that can be superposed (Senior and Senior, 1978; Wopfner, 1983; Meyer and Pena dos Reis, 1985; Thiry et al., 1988; Basile-Doelsch et al., 2005; Lee and Gilkes, 2005). They may form in weathered or unweathered materials (Wopfner, 1983; Thiry and Milnes, 1991), and are typically more massive (Thiry, 1999) and lack the systematic jointing of pedogenic varieties (Thiry and Millot, 1987) (Fig. 3b). Concretionary pillow-like, mammiform or botryoidal shapes (referred to as 'cockades' and 'glerps' in the Australian literature) are common, and have been attributed to progressive or centripetal cementation (Callender, 1978; Ruxton and Taylor, 1982; Thiry and Marechal, 2001). Similar features are reported in UK silcretes (e.g. Boswell, 1916, 1927; Davies and Baines, 1953; Hepworth, 1998).

Variations in macromorphology do, however, occur, and shapes may be very irregular in some host materials. For example, groundwater silcretes developed in limestones in the Paris Basin, where silicification is related to karstic systems, take an irregular form (Ménillet, 1988; Thiry, 1999; Thiry and Ribet, 1999). Similarly, groundwater silcretes at Stuart Creek, Australia, appear as amoeboid masses where they are developed within shales but as more massive or tuberous bodies in fluvial sands (Thiry and Milnes, 1991). Drainage-line silcretes (Fig. 3c) vary in shape from tabular to nodular (Shaw and Nash, 1998), while pan/lacustrine silcretes (Fig. 3d) may be irregularly shaped, lenticular or nodular (e.g. Armenteros et al., 1995; Ringrose et al., 2005).

In line with their profile characteristics, the micromorphology of non-pedogenic silcretes is typically simple (Fig. 5), with host material structures and fabrics generally retained (Milnes and Thiry, 1992). Geopetal features are uncommon but can occur (Callender, 1978). Unlaminated titaniferous caps, for example, have been documented on clasts within groundwater silcretes in eastern Australia (Taylor and Ruxton, 1987) and in sarsens and puddingstones from the southern UK (Ullyott et al., 2004; Ullyott and Nash, 2006; Ullyott et al., 2015) (Fig. 5d). Colloform structures with cuspate titania-rich laminae have been documented in groundwater silcretes from Australia (Taylor and Ruxton, 1987; 
Webb and Golding, 1998), but are rare; poorly developed colloform structures are also known from the UK (Ullyott et al., 2015) (Fig. 5c). Cap structures and laminar fabrics are considered further in Section 4.

Silica mineralogy is very variable within non-pedogenic silcrete cements, but vertical sequences of ripening are rarely documented. The presence of length-slow chalcedony and/or enhanced levels of moganite (>20 wt.\%) may indicate the formation of some examples under evaporitic conditions (Folk and Pittman, 1971; Heaney, 1995). Nonpedogenic silcretes can contain a variety of matrix minerals in addition to silica; this depends both on the nature of the host material and on the conditions of silicification. For example, transitions between silcrete and calcrete are frequently observed (Nash and Shaw, 1998; Nash et al., 2004). Levels of $\mathrm{TiO}_{2}$ may be significant, with both anatase and rutile reported, though these are usually present in lower concentrations than in pedogenic silcretes (Young, 1985; Taylor and Ruxton, 1987; Webb and Golding, 1998). Clay minerals, alunite and traces of zeolites have also been documented (e.g. Rodas et al., 1994; Bustillo and Bustillo, 2000), while glauconite-illite has been identified within green pan/lacustrine silcretes in the Kalahari (Summerfield, 1982; Nash et al., 2004).

\section{Problems and challenges}

While the majority of pedogenic and non-pedogenic silcretes exhibit the broad differences described above, there is an emerging literature suggesting that the basic distinction between 'complex pedogenic' and 'simple non-pedogenic' is not as clear cut as formerly suggested. Indeed, challenges to this bipartite classification arise at a variety of scales.

\subsection{Variability in silcrete macromorphology}

There are three main complications in distinguishing silcrete types at the profile scale. First, not all pedogenic silcretes display the 'typical' profile characteristics described in Section 2; columnar structures, in particular, may be absent or difficult to distinguish. For example, the 'Pierre de Stonne' silcretes in northeast France and Luxembourg, of which at least some are attributed to a pedogenic origin (Quesnel et al., 2003), can exhibit more tabular forms. Furthermore, pedogenic silcretes formed in gravelly host materials may develop columnar features at such a large scale (Thiry and Simon-Coinçon, 1996) that they may not be discernible in small exposures, drill core, or displaced boulders. Semicontinuous or lenticular pedogenic silcretes, sometimes associated with channels, have also been described (Callen, 1983; Milnes and Twidale, 1983; Milnes et al., 1991; Benbow 
et al., 1995), as have pedogenic silcrete 'skins' (Hutton et al., 1972), discrete nodules (Mišík, 1996) and veins in bedrock (Curlík and Forgác, 1996).

Second, composite profiles may be developed as a result of different silicification mechanisms operating at different times in the same area. For example, pedogenic silcrete profiles may occur superimposed on earlier groundwater silcrete profiles during progressive pedogenesis and concomitant landscape lowering (Milnes and Thiry, 1992; Thiry and Simon-Coinçon, 1996). More commonly, older pedogenic profiles are underlain by younger groundwater silcretes that have formed during later landscape dissection. Well documented examples occur in the Eromanga Basin of Australia (Milnes et al., 1991; Thiry et al., 2006), and the Apt region of southeast France (Basile-Doelsch et al., 2005), where multiple groundwater silcrete layers occur at depths of up to $100 \mathrm{~m}$ beneath surficial pedogenic silcrete.

Finally, while a number of smaller features discernible at the profile scale are often regarded as diagnostic of pedogenesis, two of the more common - tubular hollows and nodular/concretionary structures - have enigmatic origins. Vertical to sub-vertical tubular hollows are widely documented in the silcrete literature (including in sarsens and puddingstones), and are usually interpreted as rootlet or root holes. While many are undoubtedly root casts, as they retain imprints of root structures (e.g. Carruthers, 1885; Milnes and Twidale, 1983) or contain silicified roots (Clark et al., 1967; Callender, 1978; Lee and Gilkes, 2005), other formative mechanisms may also be responsible (e.g. dissolution, or bioturbation by worms, ants or termites; see Milnes et al., 1991; Benbow et al., 1995; Thiry et al., 1995; Ballesteros et al., 1997). They should not, therefore, be used to infer process. Even if undoubtedly of plant origin, the presence of root casts is only an indication that the silcrete host sediment was deposited in a relatively near-surface setting. Likewise, process should not be inferred from the presence/absence of macroscale nodular/concretionary structures, as these are also common to both pedogenic and nonpedogenic silcrete profiles and may have developed via a range of different formative processes. Instead, attention should focus on the microscale; nodular features in pedogenic silcretes commonly incorporate complex geopetal micromorphological features and occur with a suite of other illuvial features such as laminated caps or 'colloform' structures (Thiry, 1978; Milnes and Thiry, 1992), whereas those in non-pedogenic silcretes are typically large and simple in both form and micromorphology (e.g. Leckie and Cheel, 1990; Shaw and Nash, 1998). 


\subsection{Variations in silcrete micromorphology}

In addition to the problems in interpreting certain macroscale properties of silcrete profiles, a number of complications arise at the microscale. These all involve features that have been long-regarded as indicative of the role of pedogenesis in the silicification process, but which also occur in non-pedogenic silcretes. Foremost are cap structures; silica-cemented conical or cap-like features developed on the top of host sediment clasts. The origin of such structures is not entirely clear, but, particularly where caps are layered, has been suggested to relate to repetitive infiltration events (Thiry and Milnes, 1991). Many reviews of silcrete formation treat cap structures as an exclusive product of pedogenesis. However, as noted above, caps have been described in groundwater silcretes from eastern Australia and the southern UK (e.g. in the Hertfordshore puddingstone) (Fig. 5d), so cannot be considered diagnostic of pedogenic silicification. Instead, Ullyott et al. (2015) suggest that non-pedogenic silcrete caps may be distinguished from their pedogenic equivalents by their simpler form, which typically lacks laminated colloform features.

Geopetal patches or 'beards' beneath clasts have been documented in both pedogenic (Milnes et al., 1991) and groundwater silcretes (Callender, 1978). Colloform structures, often consisting of alternating laminae of silica and titania, are also described in nonpedogenic silcretes (Taylor and Ruxton, 1987; Webb and Golding, 1998; Ullyott et al., 2015), although such features appear far less abundant and well developed than in pedogenic silcretes. Finally, microscale glaebules or ped-like structures may also be found in non-pedogenic silcretes. In examples from the Kalahari, these are suggested to result from the silicification of pre-existing pedogenic calcrete (e.g. Nash et al., 1994; Nash et al., 2004), or from silica accumulation at or near the groundwater table resulting in pisolithic textures (Shaw and Nash, 1998) (Fig. 5f).

\subsection{Variations in silcrete geochemistry}

It was formerly thought that genetic types of silcrete could be distinguished on the basis of geochemistry, in particular by enrichment in titania (e.g. Summerfield and Goudie, 1980; Summerfield, 1983d). Subsequent studies have shown that the geochemistry of silcrete is considerably more complex and reflects the nature of the host material as well as the environment of silicification (e.g. Nash et al., 1994; Webb and Golding, 1998). As noted above, one type of pedogenic silcrete comprises predominantly microquartz and anatase and thus contains elevated levels of titanium (to >1\%), with low Fe, Al and K. Rarely, for example in silcrete 'skins', $\mathrm{TiO}_{2}$ may exceed 20\% (Hutton et al., 1972). The second, mainly opaline, pedogenic silcrete type retains clay and iron oxide, so is comparatively rich 
in Fe, Al and $\mathrm{K}$ but low in Ti (Thiry, 1999). Non-pedogenic silcretes are typically Ti-poor by comparison, although whether or not this is the case appears to depend on the silicified host material. For example, Webb and Golding (1998) describe Ti mobility and enrichment in non-pedogenic silcretes developed in clay-rich host materials and Ti depletion during the silicification of sandy host materials. Such a process could easily explain the variations in Ti content described in UK sarsens and puddingstones (Summerfield, 1979; Summerfield and Goudie, 1980).

\section{Conclusions: distinguishing pedogenic from non-pedogenic silcretes}

What is clear from the above discussion is that distinguishing between pedogenic and nonpedogenic silcrete can, in many cases, be difficult. To aid identification, we summarise the properties common to each silcrete type in a simple checklist (Table 1), with accompanying observations for the more problematic features noted in Section 4.

The effective use of the checklist requires that - ideally - both macromorphological and detailed micromorphological properties are considered. An understanding of the wider landscape (or palaeolandscape) context of the outcrop is also desirable; this is challenging where the silcrete is in the form of an isolated boulder or lag deposit, or is sampled from drill core, but may still be possible. Furthermore, as Ullyott et al. (2015) stress, it is not simply the presence/absence of individual indicators that should be taken into account, but rather the combination, abundance and degree of development of features.

For example, an extensive silcrete outcrop that (i) caps a palaeosurface, (ii) exhibits a vertically-differentiated profile with a columnar structure at the macroscale, plus (iii) upward-ripening cements and abundant, well-developed, way-up orientated features (e.g. cuspate colloform and laminated cap structures) at the microscale, will almost certainly have formed as a result of pedogenic silicification. A more localised massive outcrop lacking vertical profile differentiation at the macroscale, but with abundant complex way-up micro-features, may also be a pedogenic silcrete. In contrast, a silcrete with a similar simple profile but lacking complex internal structural features is more likely to have formed via non-pedogenic mechanisms. At this stage it would be necessary to assess the geomorphic (or palaeo-geomorphic) context of the outcrop to determine whether it was a groundwater, drainage-line or pan/lacustrine silcrete.

As this review has demonstrated, the silcrete literature has grown to the stage that we now have a good understanding of the external and internal features associated with pedogenic silicification. Much more research is needed, however, into the properties of 
non-pedogenic silcretes. While the literature on groundwater and pan/lacustrine silcretes is reasonably abundant, only a handful of studies from southern Africa and Australia have focussed on drainage-line varieties. A better understanding of micro-structures within nonpedogenic silcretes - particularly those such as glaebules/nodules, caps, colloform structures and beard-like features that also occur within pedogenic varieties - will greatly improve our ability to distinguish silcrete types in the landscape and geological record.

\section{References}

Alley, N.F., 1998. Cainozoic stratigraphy, palaeoenvironments and geological evolution of the Lake Eyre Basin. Palaeogeography Palaeoclimatology Palaeoecology 144, 239-263.

Armenteros, I., Bustillo, M.A., Blanco, J.A., 1995. Pedogenic and groundwater processes in a closed Miocene basin (Northern Spain). Sedimentary Geology 99, 17-36.

Baele, J.-M., Cnudde, V., Quesnel, F., Ricordel-Prognon, C., Veldman, I., 2012. Recognizing pedogenic features in Paleogene sandstones and silcretes in Belgium. A key feature for palaoenvironmental and sourcing material studies, 4th International Geologica Belgica Meeting, p. 275.

Ballesteros, E.M., Talegón, J.G., Hernández, M.A., 1997. Palaeoweathering profiles developed on the Iberian Hercynian basement and their relationship to the oldest Tertiary surface in central and western Spain, In: Widdowson, M. (Ed.), Palaeosurfaces: Recognition, Reconstruction and Palaeoenvironmental Interpretation. Special Publication 120. Geological Society, London, pp. 175185.

Basile-Doelsch, I., Meunier, J.D., Parron, C., 2005. Another continental pool in the terrestrial silicon cycle. Nature 433, 399-402.

Benbow, M.C., Callen, R.A., Bourman, R.P., Alley, N.F., 1995. Deep weathering, ferricrete and silcrete, In: Drexel, J.F., Preiss, W.V. (Eds.), Bulletin 54: The Geology of South Australia, Volume 2: the Phanerozoic. Geological Survey of South Australia, pp. 201-207.

Boswell, P.G.H., 1916. On the Eocene deposits of the London Basin. Quarterly Journal of the Geological Society of London 71, 536-575.

Boswell, P.G.H., 1927. The geology of the country near Ipswich. Memoir of the Geological Survey. HMSO, London.

Brown, K.S., Marean, C.W., Herries, A.I.R., Jacobs, Z., Tribolo, C., Braun, D., Roberts, D.L., Meyer, M.C., Bernatchez, J., 2009. Fire as an engineering tool of early modern humans. Science $325,859-862$.

Bustillo, M.A., Bustillo, M., 1993. Rhythmic lacustrine sequences with silcretes from the Madrid Basin, Spain: Geochemical trends. Chemical Geology 107, 229-232.

Bustillo, M.A., Bustillo, M., 2000. Miocene silcretes in argillaceous playa deposits, Madrid Basin, Spain: petrological and geochemical features. Sedimentology 47, 1023-1037.

Callen, R.A., 1983. Late Tertiary grey billy and the age and origin of surficial silicifications (silcrete) in South-Australia. Journal of the Geological Society of Australia 30, 393-410. 
Callender, J.H., 1978. A study of the silcretes near Marulan and Milton, New South Wales, In: Langford-Smith, T. (Ed.), Silcrete in Australia. University of New England Press, Armidale, pp. 209221.

Carruthers, W., 1885. Notes on fossil roots in the sarsen stones of Wiltshire. Geological Magazine (Decade III) 2, 361-362.

Clark, M.J., Lewin, J., Small, R.J., 1967. The sarsen stones of the Marlborough Downs and their geomorphological implications. Southampton Research Series in Geography 4, 3-40.

Curlík, J., Forgác, J., 1996. Mineral forms and silica diagenesis in weathering silcretes of volcanic rocks in Slovakia. Geologica Carpathica 47, 107-118.

Davies, A.M., Baines, A.H.J., 1953. A preliminary survey of the sarsen and puddingstone blocks of the Chilterns. Proceedings of the Geologists' Association 64, 1-9.

Dubroeucq, D., Thiry, M., 1994. Indurations siliceuses dans des sols volcaniques. Comparaison avec des silcrètes anciens. Transactions of the 15th World Congress of Soil Sciences, Acapulco, Mexico, July 10-16, 1994 6a, 445-459.

Folk, R.L., Pittman, J.S., 1971. Length-slow chalcedony: a new testament for vanished evaporites. Journal of Sedimentary Petrology 41, 1045-1058.

Fookes, P.G., Hart, A.B., Lee, E.M., 2013. Some near-surface desert features of significance in engineering geology evaluations. Quarterly Journal of Engineering Geology and Hydrogeology 46, 259-266.

Frankel, J.J., Kent, L.E., 1938. Grahamstown surface quartzites (silcretes). Transactions of the Geological Society of South Africa 15, 1-42.

Goudie, A.S., 1973. Duricrusts in Tropical and Subtropical Landscapes. Clarendon Press, Oxford.

Green, C.P., 1997. Stonehenge: geology and prehistory. Proceedings of the Geologists' Association 108, 1-10.

Heaney, P.J., 1995. Moganite as an indicator for vanished evaporites: a testament reborn? Journal of Sedimentary Research A65, 633-638.

Hepworth, J.V., 1998. Aspects of the English silcretes and comparison with some Australian occurrences. Proceedings of the Geologists Association 109, 271-288.

Hutton, J.T., Twidale, C.R., Milnes, A.R., Rosser, H., 1972. Composition and genesis of silcretes and silcrete skins from the Beda valley, southern Arcoona plateau, South Australia. Journal of the Geological Society of Australia 19, 31-39.

Isaac, K.P., 1983. Silica diagenesis of Palaeogene residual deposits in Devon, England. Proceedings of the Geologists' Association 94, 181-186.

Jones, D.K.C., 1999. Evolving models of the Tertiary evolutionary geomorphology of southern England, with special reference to the chalklands, In: Whalley, W.B., Smith, B.J., Widdowson, M. (Eds.), Uplift, Erosion and Stability, Special Publication 162. Geological Society, London, pp. 1-24.

Kendrick, K.J., Graham, R.C., 2004. Pedogenic silica accumulation in chronosequence soils, Southern California. Soil Science Society of America Journal 68, 1295-1303.

Langford-Smith, T., 1978. A select review of silcrete research in Australia, In: Langford-Smith, T. (Ed.), Silcrete in Australia. University of New England Press, Armidale, pp. 1-11. 
Leckie, D.A., Cheel, R.J., 1990. Nodular silcretes of the cypress Hills Formation (Upper Eocene to Middle Miocene) of southern Saskatchewan, Canada. Sedimentology 37, 445-454.

Lee, S.Y., Gilkes, R.J., 2005. Groundwater geochemistry and composition of hardpans in southwestern Australian regolith. Geoderma 126, 59-84.

Lovell, B., 2015. Hertfordshire Puddingstone: relationship to the Paleocene-Eocene Thermal Maximum and a perspective on human-induced climate change. Proceedings of the Geologists' Association 126, 8-13.

Ménillet, F., 1988. Les accident siliceux des calcaires continentaux à lacustres du Tertiaire du Bassin de Paris. Bulletin d'Information des géologiques du Bassin de Paris 25, 57-70.

Meyer, R., Pena dos Reis, R.B., 1985. Paleosols and alunite silcretes in continental Cenozoic of western Portugal. Journal of Sedimentary Petrology 55, 76-85.

Milnes, A.R., Twidale, C.R., 1983. An overview of silicification in Cainozoic landscapes of arid central and southern Australia. Australian Journal of Soil Research 21, 387-410.

Milnes, A.R., Wright, M.J., Thiry, M., 1991. Silica accumulations in saprolites and soils in South Australia, In: Nettleton, W.D. (Ed.), Occurrence, Characteristics and Genesis of Carbonate, Gypsum, and Silica Accumulations in Soils. Soil Science Society of America Special Publication 26, pp. 121-149.

Milnes, A.R., Thiry, M., 1992. Silcretes, In: Martini, I.P., Chesworth, W. (Eds.), Weathering, Soils and Palaeosols. Developments in Earth Surface Processes 2. Elsevier, Amsterdam, pp. 349-377.

Mišík, M., 1996. Silica spherulites and fossil silcretes in carbonate rocks of the Western Carpathians. Geologica Carpathica 47, 91-105.

Mountain, E.D., 1952. The origin of silcrete. South African Journal of Science 48, 201-204.

Mountain, E.D., 1980. Grahamstown peneplain. Transactions of the Geological Society of South Africa 83, 47-53.

Nash, D.J., Thomas, D.S.G., Shaw, P.A., 1994. Siliceous duricrusts as palaeoclimatic indicators: evidence from the Kalahari Desert of Botswana. Palaeogeography Palaeoclimatology Palaeoecology 112, 279-295.

Nash, D.J., Shaw, P.A., 1998. Silica and carbonate relationships in silcrete-calcrete intergrade duricrusts from the Kalahari of Botswana and Namibia. Journal of African Earth Sciences 27, $11-$ 25.

Nash, D.J., Shaw, P.A., Ullyott, J.S., 1998. Drainage-line silcretes of the Middle Kalahari: an analogue for Cenozoic sarsen trains? Proceedings of the Geologists Association 109, 241-254.

Nash, D.J., McLaren, S.J., Webb, J.A., 2004. Petrology, geochemistry and environmental significance of silcrete-calcrete intergrade duricrusts at Kang Pan and Tswaane, Central Kalahari, Botswana. Earth Surface Processes and Landforms 29, 1559-1586.

Nash, D.J., Ullyott, J.S., 2007. Silcrete, In: Nash, D.J., McLaren, S.J. (Eds.), Geochemical Sediments and Landscapes. Blackwell, Oxford, pp. 95-143.

Nash, D.J., Coulson, S., Staurset, S., Ullyott, J.S., Babutsi, M., Hopkinson, L., Smith, M.P., 2013. Provenancing of silcrete raw materials indicates long-distance transport to Tsodilo Hills, Botswana, during the Middle Stone Age. Journal of Human Evolution 64, 280-288. 
Quesnel, F., Théveniaut, H., Voisin, L., Wyns, R., 2003. The "Pierre de Stonne" and the "Bonne de fer", as main features of Meso-Cenozoic paleoweathering of the Upper Lorraine and Ardennian Thiériache areas, In: Quesnel, F. (Ed.), Paleoweathering and paleosurfaces in the Ardenne-Eifel region. Bureau de Recherches Géologiques et Minières, Orléans, pp. 11-28.

Ringrose, S., Huntsman-Mapila, P., Basira Kampunzu, A., Downey, W., Coetzee, S., Vink, B., Matheson, W., Vanderpost, C., 2005. Sedimentological and geochemical evidence for palaeoenvironmental change in the Makgadikgadi subbasin, in relation to the MOZ rift depression, Botswana. Palaeogeography, Palaeoclimatology, Palaeoecology 217, 265-287.

Rodas, M., Luque, F.J., Mas, R., Garzon, M.G., 1994. Calcretes, palycretes and silcretes in the Paleogene detrital sediments of the Duero and Tajo Basins, Central Spain. Clay Minerals 29, 273285.

Rogers, J., 1980. First Report on the Cenozoic Sediments between Cape Town and Elands Bay. Report 136. Geological Survey of South Africa, Pretoria.

Ruxton, B.P., Taylor, G., 1982. The Cainozoic geology of the Middle Shoalhaven Plain. Journal of the Geological Society of Australia 29, 239-246.

Schmidt, P., Porraz, G., Slodczyk, A., Bellot-Gurlet, L., Archer, W., Miller, C.E., 2013. Heat treatment in the South African Middle Stone Age: temperature induced transformations of silcrete and their technological implications. Journal of Archaeological Science 40, 3519-3531.

Senior, B.R., Senior, D.A., 1978. Silcrete in southwest Queensland. Bulletin of the Bureau of Mineral Resources, Geology and Geophysics of Australia 60, 761-776.

Shaw, P.A., Nash, D.J., 1998. Dual mechanisms for the formation of fluvial silcretes in the distal reaches of the Okavango Delta Fan, Botswana. Earth Surface Processes and Landforms 23, 705714.

Summerfield, M.A., 1979. Origin and paleoenvironmental interpretation of sarsens. Nature 281, 137-139.

Summerfield, M.A., Goudie, A.S., 1980. The sarsens of southern England: their palaeoenvironmental interpretation with reference to other silcretes, In: Jones, D.K.C. (Ed.), The Shaping of Southern England. Academic Press, London, pp. 71-100.

Summerfield, M.A., 1981. The nature and occurrence of silcrete, southern Cape Province, South Africa. School of Geography Research Paper 28. University of Oxford, Oxford.

Summerfield, M.A., 1982. Distribution, nature and genesis of silcrete in arid and semi-arid southern Africa. Catena Supplement 1, 37-65.

Summerfield, M.A., 1983a. Petrography and diagenesis of silcrete from the Kalahari Basin and Cape coastal zone, southern Africa. Journal of Sedimentary Petrology 53, 895-909.

Summerfield, M.A., 1983b. Geochemistry of weathering profile silcretes, southern Cape Province, South Africa, In: Wilson, R.C.L. (Ed.), Residual Deposits: Surface Related Weathering Processes and Materials. Special Publication 11. Geological Society, London, pp. 167-178.

Summerfield, M.A., 1983c. Silcrete, In: Goudie, A.S., Pye, K. (Eds.), Chemical Sediments and Geomorphology. Academic Press, London, pp. 59-91.

Summerfield, M.A., 1983d. Silcrete as a paleoclimatic indicator - evidence from southern Africa. Palaeogeography Palaeoclimatology Palaeoecology 41, 65-79. 
Taylor, G., 1978. Silcretes in the Walgett-Cumborah region of New South Wales, In: LangfordSmith, T. (Ed.), Silcrete in Australia. University of New England Press, Armidale, pp. 187-193.

Taylor, G., Ruxton, B.P., 1987. A duricrust catena in southeast Australia. Zeitschrift für Geomorphologie 31, 385-410.

Terry, D.O., Evans, J.E., 1994. Pedogenesis and paleoclimatic implications of the Chamberlain Pass Formation, Basal White River Group, Badlands of South-Dakota. Palaeogeography Palaeoclimatology Palaeoecology 110, 197-215.

Thiry, M., 1978. Silicification des sédiments sablo-argileux de l'Yprésien du sud-est du bassin de Paris. Genèse et évolution des dalles quartzitiques et silcrètes. Bulletin du Bureau de Recherches Géologiques et Minières (deuxième série) 1, 19-46.

Thiry, M., 1981. Sédimentation continentale et altérations associées: calcitisations, ferruginisations et silicifications, Les Argiles Plastiques de Sparnacien du Bassin de Paris. Sciences Géologiques, Mémoire 64.

Thiry, M., Turland, M., 1985. Paléotoposéquences de sols ferrugineux et de cuirassements siliceux dans le Sidérolithique du nord du Massif Central. Géologie de France 2, 175-192.

Thiry, M., Millot, G., 1987. Mineralogical forms of silica and their sequence of formation in silcretes. Journal of Sedimentary Petrology 57, 343-352.

Thiry, M., 1988. Les Grès lustrés de l'Éocène du Bassin de Paris: des silcrètes pédologiques. Bulletin d'Information des Géologues du Bassin de Paris 25, 15-24.

Thiry, M., Ayrault, M.B., Grisoni, J.C., 1988. Groundwater silicification and leaching in sands example of the Fontainebleau sand (Oligocene) in the Paris Basin. Geological Society of America Bulletin 100, 1283-1290.

Thiry, M., Ben Brahim, M., 1990. Silicifications pédogénétiques dans les dépôts hamadiens du piémont de Boudenib (Maroc). Geodinamica Acta 4, 237-251.

Thiry, M., Milnes, A.R., 1991. Pedogenic and groundwater silcretes at Stuart Creek opal field, South Australia. Journal of Sedimentary Petrology 61, 111-127.

Thiry, M., Schmitt, J.M., Rayot, V., Milnes, A.R., 1995. Geochemistry of the bleached profiles of the Tertiary regolith of inland Australia. Comptes Rendus de l'Académie des Sciences Série II 320, 279-285.

Thiry, M., Simon-Coinçon, R., 1996. Tertiary palaeoweatherings and silcretes in the southern Paris Basin. Catena 26, 1-26.

Thiry, M., 1999. Diversity of continental silicification features: examples from the Cenozoic deposits in the Paris Basin and neighbouring basement, In: Thiry, M., Simon-Coinçon, R. (Eds.),

Palaeoweathering, Palaeosurfaces and Related Continental Deposits. International Association of Sedimentologists, Special Publication No 27. Blackwell Science, Oxford, pp. 87-127.

Thiry, M., Ribet, I., 1999. Groundwater silicification in Paris Basin limestones: fabrics, mechanisms, and modeling. Journal of Sedimentary Research 69, 171-183.

Thiry, M., Marechal, B., 2001. Development of tightly cemented sandstone lenses in uncemented sand: example of the Fontainebleau sand (Oligocene) in the Paris Basin. Journal of Sedimentary Research A71, 473-483. 
Thiry, M., Milnes, A.R., Rayot, V., Simon-Coinçon, R., 2006. Interpretation of palaeoweathering features and successive silicifications in the Tertiary regolith of inland Australia. Journal of the Geological Society, London 163, 723-736.

Thiry, M., Milnes, A., Ben Brahim, M., 2015. Pleistocene cold climate groundwater silicification, Jbel Ghassoul region, Missour Basin, Morocco. J. Geol. Soc. 172, 125-137.

Ullyott, J.S., Nash, D.J., Shaw, P.A., 1998. Recent advances in silcrete research and their implications for the origin and palaeoenvironmental significance of sarsens. Proceedings of the Geologists' Association 109, 255-270.

Ullyott, J.S., Nash, D.J., Whiteman, C.A., Mortimore, R.N., 2004. Distribution, petrology and mode of development of silcretes (sarsens and puddingstones) on the eastern South Downs, UK. Earth Surface Processes and Landforms 29, 1509-1539.

Ullyott, J.S., Nash, D.J., 2006. Micromorphology and geochemistry of groundwater silcretes in the eastern South Downs, UK. Sedimentology 53, 387-412.

Ullyott, J.S., Nash, D.J., Huggett, J.M., 2015. Cap structures as diagnostic indicators of silcrete origin. Sedimentary Geology 325, 119-131.

van der Graaff, W.J.E., 1983. Silcrete in Western Australia: geomorphological settings, textures, structures, and their possible genetic implications, In: Wilson, R.C.L. (Ed.), Residual Deposits: Surface Related Weathering Processes and Materials. Special Publication 11. Geological Society, London, pp. 159-166.

Watts, S.H., 1978. The nature and occurrence of silcrete in the Tibooburra area of northwestern New South Wales, In: Langford-Smith, T. (Ed.), Silcrete in Australia. University of New England Press, Armidale, pp. 167-185.

Webb, J.A., Golding, S.D., 1998. Geochemical mass-balance and oxygen-isotope constrains on silcrete formation and its paleoclimatic implications in Southern Australia. Journal of Sedimentary Research 68, 981-993.

Wopfner, H., 1978. Silcretes of northern South Australia and adjacent regions, In: Langford-Smith, T. (Ed.), Silcrete in Australia. University of New England Press, Armidale, pp. 93-141.

Wopfner, H., 1983. Environment of silcrete formation: a comparison of examples from Australia and the Cologne Embayment, West Germany, In: Wilson, R.C.L. (Ed.), Residual Deposits: Surface Related Weathering Processes and Materials. Special Publication 11. Geological Society, London, pp. 151-157.

Young, R.W., 1978. Silcrete in a humid landscape: the Shoalhaven Valley and adjacent coastal plains of southern New South Wales, In: Langford-Smith, T. (Ed.), Silcrete in Australia. University of New England Press, Armidale, pp. 195-207.

Young, R.W., 1985. Silcrete distribution in eastern Australia. Zeitschrift für Geomorphologie 29, 2136. 


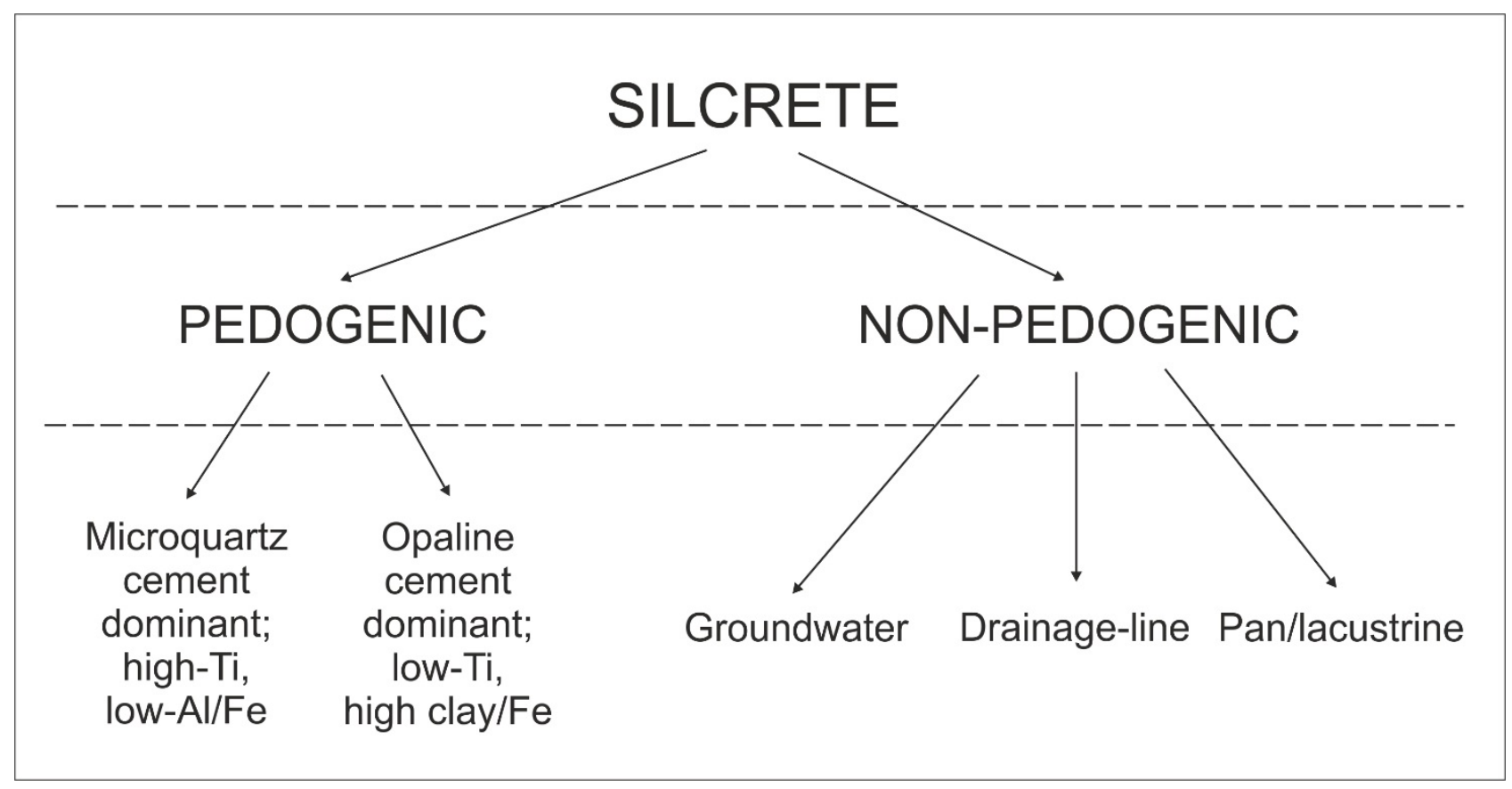

Figure 1: Classification of silcrete (Nash and Ullyott, 2007). 

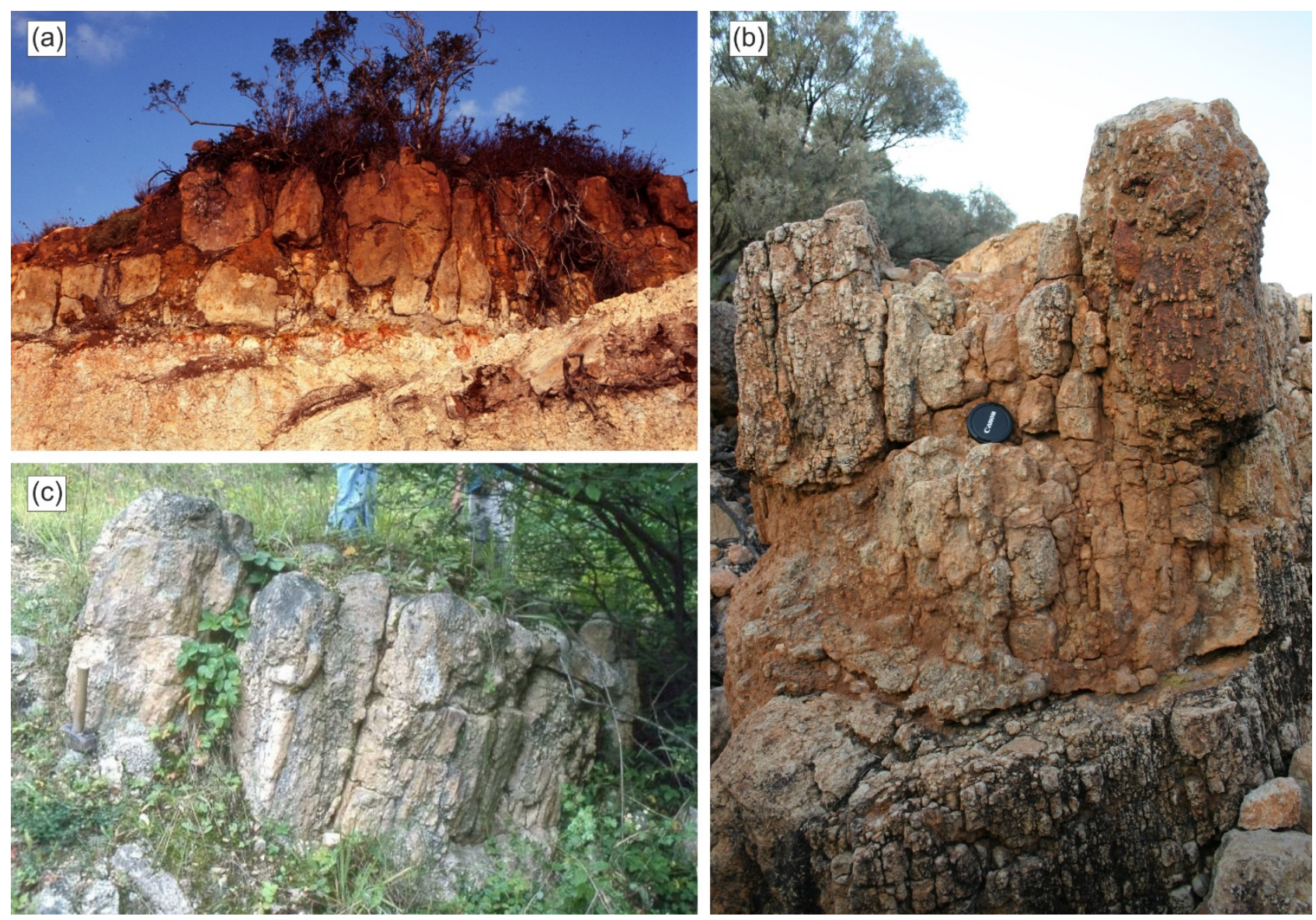

Figure 2: Typical pedogenic silcrete profiles from (a) Enniskillin, Western Cape, South Africa; (b) Mount Wood Hills, near Tibooburra, New South Wales, Australia; and (c) Montagny-Lencoup, Paris Basin, France. Note the columnar structure of all three profiles and the well-developed 'candle-wax' drip-like macro-structures in image (c). 

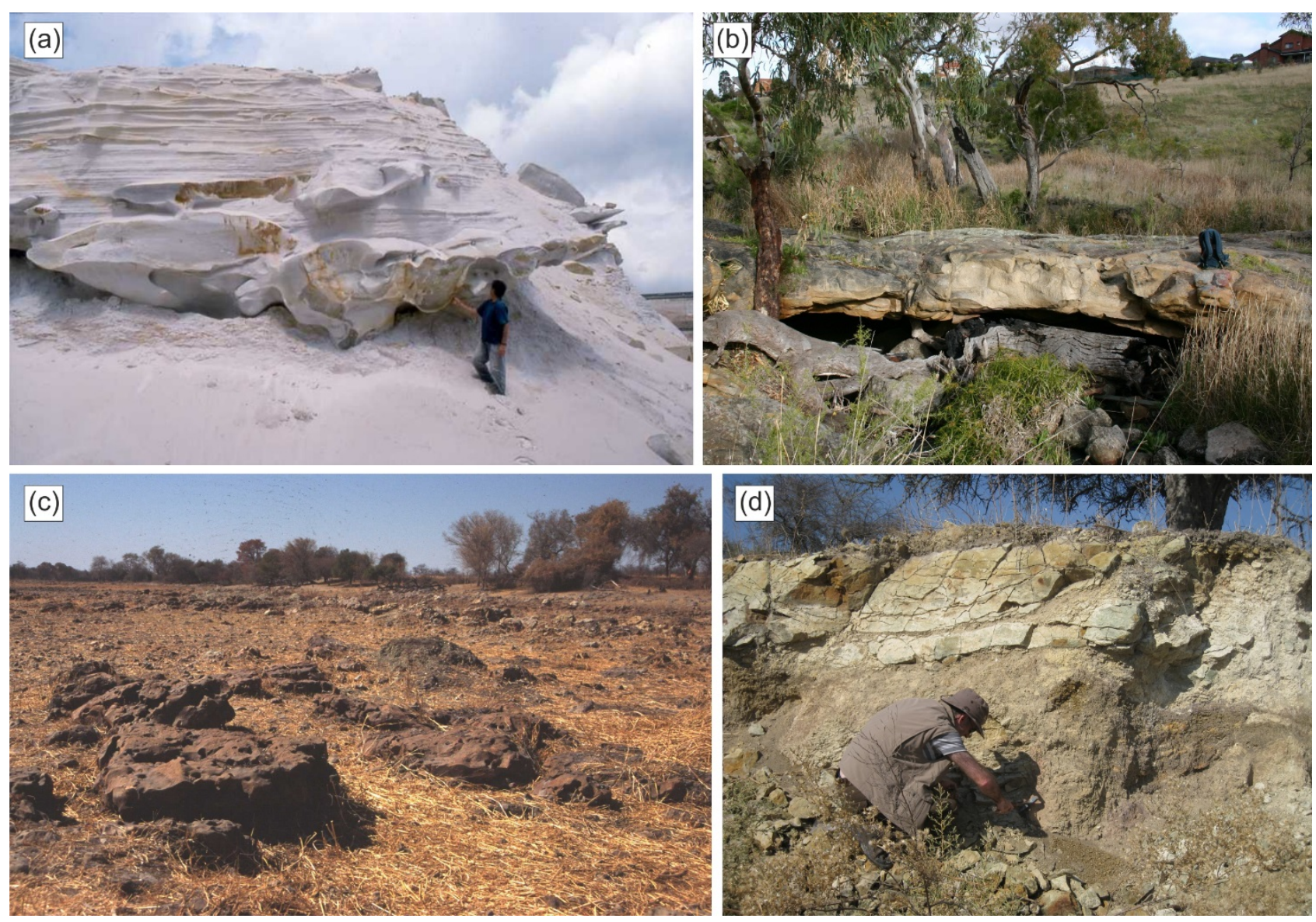

Figure 3: Examples of non-pedogenic silcrete outcrops: (a) Superposed groundwater silcrete lenses developed within Fontainebleau Sand at Bonnevault Quarry, Paris Basin, France; (b) Groundwater silcrete developed within Red Bluff Sand at Taylor Creek, north of Melbourne, Australia; (c) Drainage-line silcrete in the floor of the Boteti River near Samedupe Drift, Botswana; (d) Pan/lacustrine silcrete exposed at the southern margin of Lake Ngami, Botswana. 

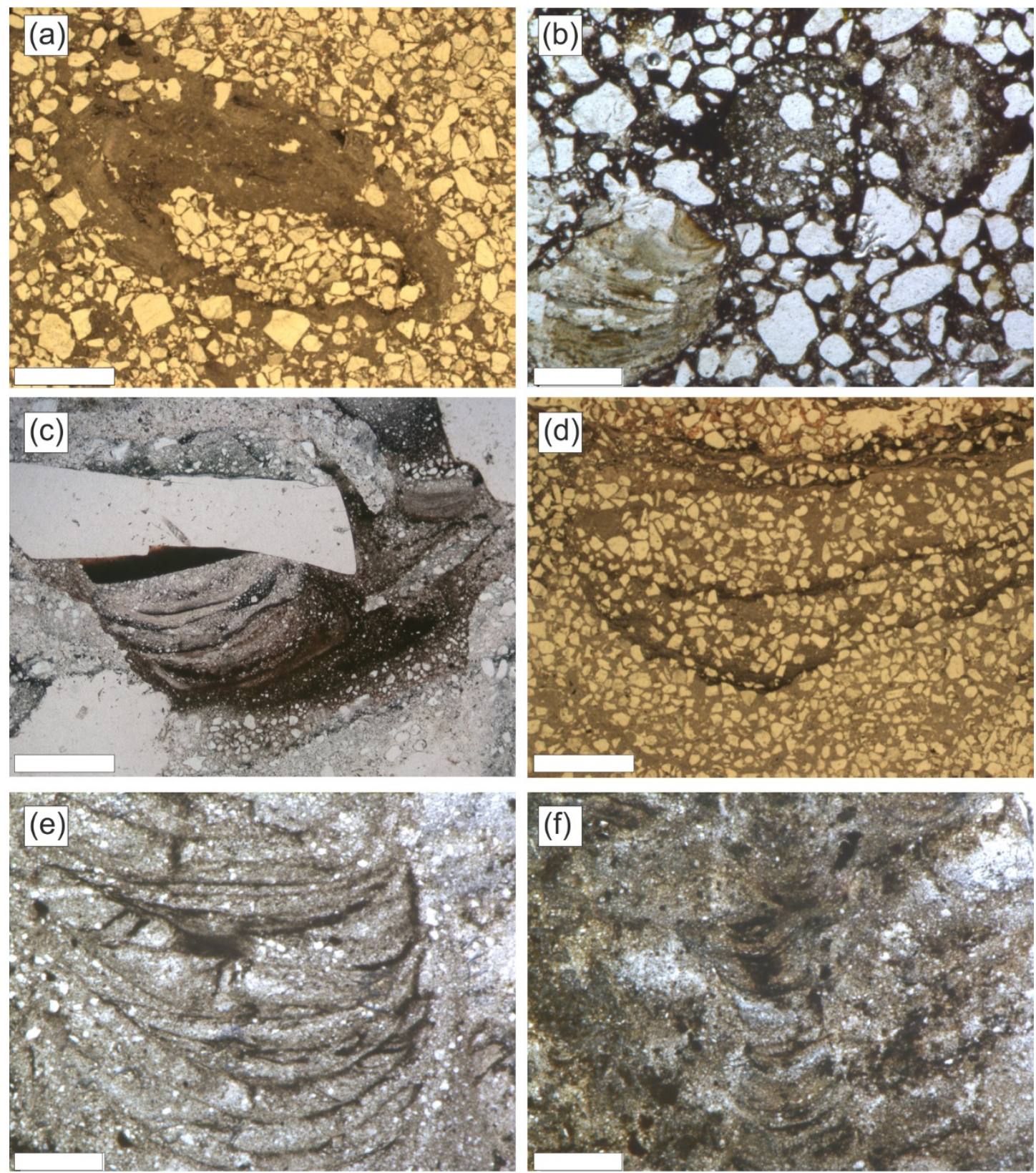

Figure 4: Photomicrographs of microscale structures within pedogenic silcretes: (a) Glaebular structure within a pedogenic silcrete from Stuart Creek, South Australia (plain polarised light, scale bar $2 \mathrm{~mm}$, image courtesy of John Webb); (b) Glaebular (top right) and cuspate colloform structures (bottom left) within a pedogenic silcrete from Makanna's Kop, Grahamstown, Eastern Cape, South Africa (plain polarised light, scale bar $500 \mu \mathrm{m}$ ); Cuspate colloform structures within pedogenic silcretes from (c) Salcombe Hill, Sidmouth, Devon, UK (plain polarised light, scale bar $1 \mathrm{~mm}$ ) (d) Stuart Creek, South Australia (plain polarised light, scale bar $2 \mathrm{~mm}$, image courtesy of John Webb), (e and f) north of Albertinia, Western Cape, South Africa (plain polarised light, scale bar $500 \mu \mathrm{m}$ ). 

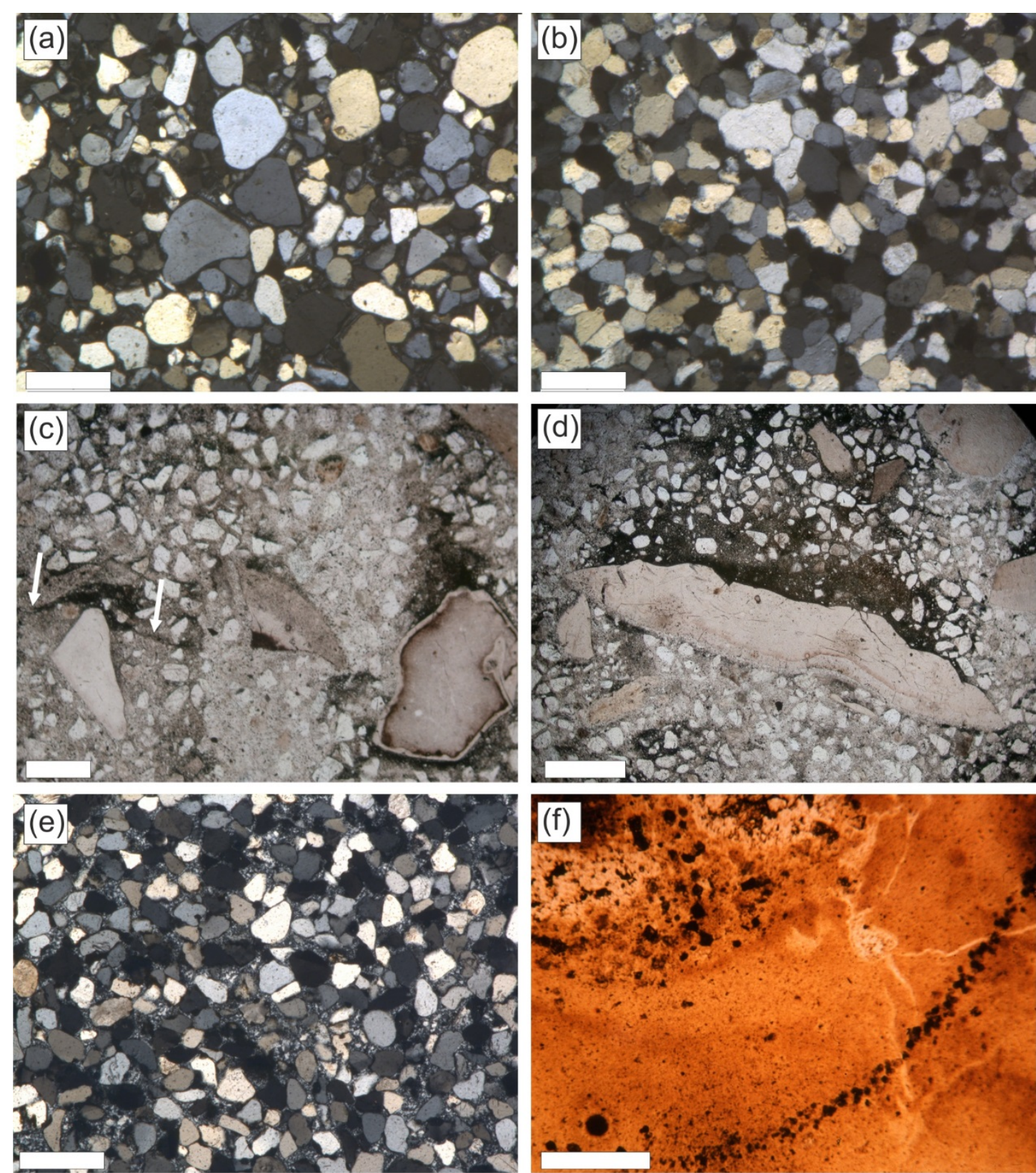

Figure 5: Photomicrographs of microscale structures within non-pedogenic silcretes: (a) pan/lacustrine silcrete from the southern margin of Lake Ngami, Botswana (cross polarised light, scale bar $500 \mu \mathrm{m}$ ); (b) groundwater silcrete from Roche des Etroitures, near Fontainebleau, Paris Basin, France (cross polarised light, scale bar $500 \mu \mathrm{m}$ ); (c) poorly developed cuspate feature (arrowed) within a groundwater silcrete (puddingstone) from Ley Hill, Chesham, UK (plain polarised light, scale bar $200 \mu \mathrm{m}$ ); (d) cap structure within a groundwater silcrete (puddingstone) from Ley Hill, Chesham, UK (plain polarised light, scale bar $1 \mathrm{~mm}$ ), (e) drainage-line silcrete from Samedupe Drift, Boteti River, Botswana (cross polarised light, scale bar $500 \mu \mathrm{m}$ ); (f) pisolithic structure towards the base of the same drainage-line silcrete as (e) (plain polarised light, scale bar $500 \mu \mathrm{m}$ ). 
Table 1: Distinguishing pedogenic from non-pedogenic silcrete varieties.

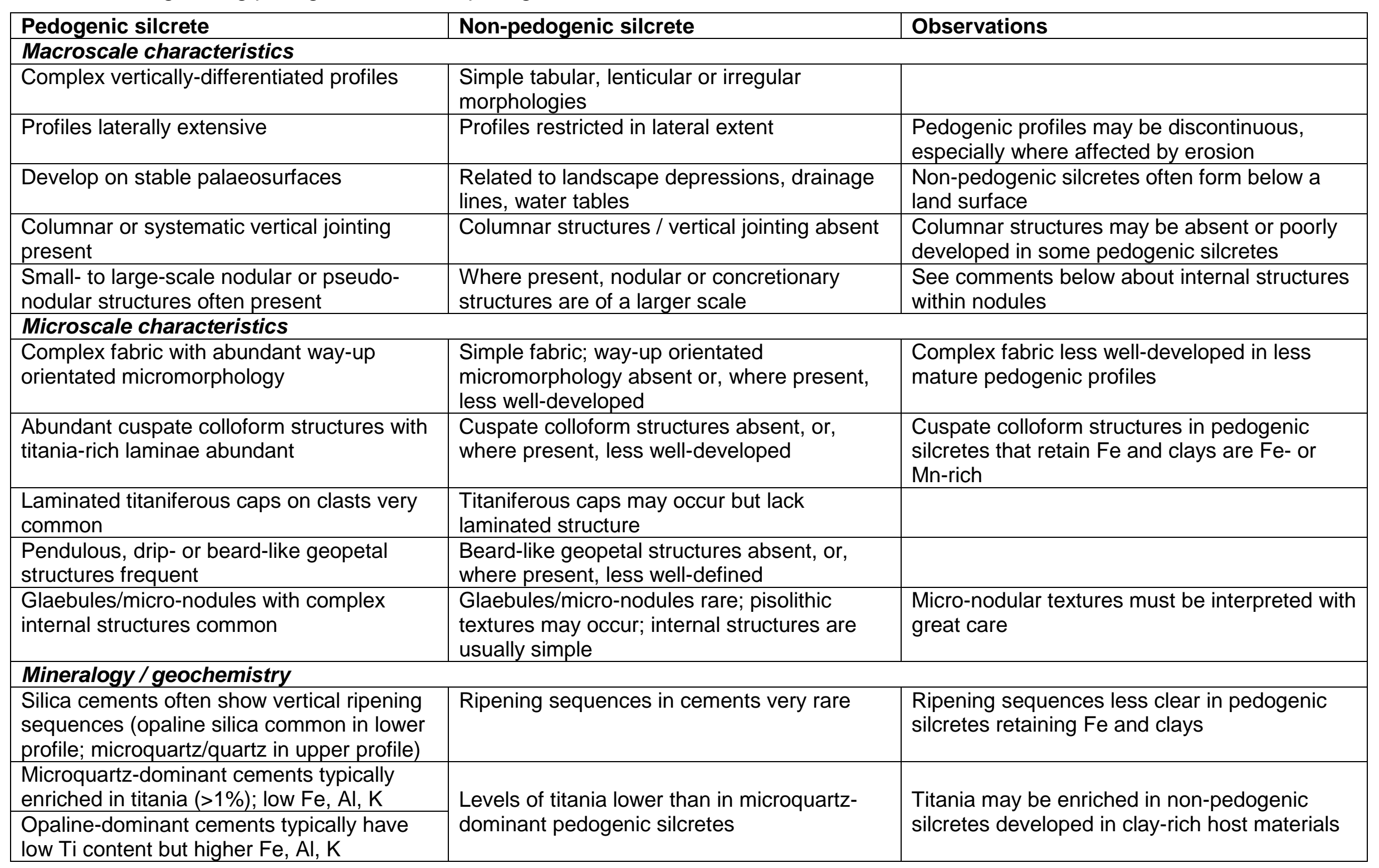

